\title{
A Possible Mechanism for the Cellular Coaggregation between Actinomyces viscosus ATCC 19246 and Streptococcus sanguis ATCC 10557
}

\author{
By SETSUKO SATO, TOSHIHIKO KOGA† AND MASAKAZU INOUE* \\ Department of Preventive Dentistry, Kagoshima University Dental School, 1208-1, Usuki-Cho, \\ Kagoshima 890, Japan
}

(Received 9 August 1983; revised 4 January 1984)

\begin{abstract}
The cells of Actinomyces viscosus ATCC 19246 (Av19246) and Streptococcus sanguis ATCC 10557 (Ss10557) coaggregated immediately after mixing in $40 \mathrm{~mm}$-Tris/HCl buffer. Optimal conditions were $\mathrm{pH} 7 \cdot 5$ in the presence of $\mathrm{Ca}^{2+}$ at $0.1 \mathrm{mM}$ or higher. $\mathrm{Na}_{2}$ EDTA and its analogues, $\mathrm{Na}_{2} \mathrm{MgEDTA}$ and $\mathrm{Na}_{2} \mathrm{MnEDTA}$ at $7.5 \mathrm{mM}$ inhibited the coaggregation. Trypsin and heat treatment impaired the reactive site on Av19246 cells, but not on Ss 10557 cells. The coaggregates, once formed, dissociated gradually during extended incubation at $37{ }^{\circ} \mathrm{C}$; this was prevented by addition of sufficient $\mathrm{Ca}^{2+}$. The disaggregation appears to be a spontaneous denaturation of the proteinaceous reactive site on Av19246 cell surface. Thus, the coaggregation involves the interaction of a lectin-like substance on the surface of Av19246 with a carbohydrate site on Ss10557. Native Ss 10557 cell walls possessed reactivity with Av19246 cells but $5 \%(\mathrm{w} / \mathrm{v})$ TCA-extracted cell wall residues did not. A carbohydrate moiety extracted from Ss 10557 exhibited a high potency in blocking coaggregation, and coaggregates were dissociated upon addition of the carbohydrate. Lactose, galactose and $N$-acetyl-D-galactosamine (the latter two are major constituents of the antigen extract) also significantly inhibited the coaggregation, but the other antigen components, glucose and rhamnose, did not. Relative inhibitory activity, expressed as molar potency, of carbohydrate antigen, lactose, galactose and $N$-acetyl-Dgalactosamine respectively, was approximately $26 \times 10^{3}: 16: 4: 1$. Ss 10557 cells and cell walls reacted only with a Ricinus communis (castor bean) agglutinin-120 but not with Glycine max (soybean) agglutinin, Arachis hypogaea (peanut) agglutinin or Phaseolus vulgaris agglutinin (phytohaemagglutinin). These results suggest that the reaction site on Ss 10557 cells comprises a D-galactose- $(1 \rightarrow 4)-\beta$-D-glucose- sequence and that $\mathrm{N}$-acetyl-D-galactosamine (an immunodeterminant of the streptococcus strain) appears not to be involved in the coaggregation reaction.
\end{abstract}

\section{INTRODUCTION}

Actinomyces viscosus has been implicated in the aetiology of root surface caries and periodontal disease (Jordan \& Keyes, 1964; Jordan \& Hammond, 1972). Streptococcus sanguis is reported to be the most predominant organism in human dental plaque, particularly in the earliest stages of plaque formation (Socransky et al., 1977).

Gibbons \& Nygaard (1970) observed specific coaggregations of paired oral bacteria of different species, including a pair of $A$. viscosus and $S$. sanguis, and suggested that the coaggregation plays an important role in the accumulation of oral bacteria on teeth. It has been reported that coaggregations between certain strains of $S$. sanguis and specific strains of $A$. viscosus occur by lectin-carbohydrate interactions of cell surface components (Ellen \& Balcerzak-Raczkowski, 1977; McIntire et al., 1978; Cisar et al., 1979; Kolenbrander \& Williams, 1981; McIntire et al., 1982). The presence of five complementary pairs of cell surface

$\dagger$ Present address: Department of Dental Research, National Institute of Health, Kamiosaki, Shinagawa-Ku, Tokyo 141, Japan 
components has been proposed (Kolenbrander \& Williams, 1981). Three of these are lactosenon-reversible and two are lactose-reversible. In lactose-reversible cases, the reactive sites of a protein or glycoprotein nature reside on $A$. viscosus and the sites of a carbohydrate nature are on S. sanguis.

In the course of studies on the cell surface components of oral streptococci, we found that glucose-grown cells of $S$. sanguis ATCC 10557 and cells of $A$. viscosus ATCC 19246 immediately formed large aggregates under certain conditions but gradually disaggregated during incubation. In this paper we describe the general nature of the interaction and characterization of the surface molecules involved, giving special emphasis to the $S$. sanguis components, and we discuss a possible mechanism for the coaggregation.

\section{METHODS}

Preparation of A. viscosus and S. sanguis cells. Streptococcus sanguis ATCC 10557 (Ss10557, serotype II; Hamada et al., 1980) and A. viscosus ATCC 19246 (Av19246) were kindly provided by Dr S. Hamada (Department of Dental Research, National Institute of Health, Tokyo, Japan). These strains were grown aerobically in Brain Heart Infusion broth (BHI; BBL Microbiology Systems, Cockeysville, Md., USA) at $37^{\circ} \mathrm{C}$ for $18 \mathrm{~h}$. Cells were harvested by centrifugation and were washed three times with $40 \mathrm{~mm}-\mathrm{Tris} / \mathrm{HCl}$ buffer, $\mathrm{pH} 7 \cdot 5$. The cells were suspended in distilled water to give an $\mathrm{OD}_{550}$ of $0 \cdot 75$. Since the Av19246 cells aggregated spontaneously in distilled water, their suspensions were homogenized ultrasonically prior to the measurement of turbidity.

A portion of either Av19246 or Ss 10557 cells suspended in $40 \mathrm{mM}-\mathrm{Tris} / \mathrm{HCl}$ buffer, $\mathrm{pH} 7 \cdot 5$, was heated at $100^{\circ} \mathrm{C}$ for $1 \mathrm{~min}$, at $80^{\circ} \mathrm{C}$ for $5 \mathrm{~min}$, or incubated with trypsin at $100 \mu \mathrm{g} \mathrm{ml} \mathrm{l}^{-1}\left(1: 250\right.$; Difco), at $37^{\circ} \mathrm{C}$ for $3 \mathrm{~h}$. Ss 10557 cells were also extracted in $1 \%(\mathrm{v} / \mathrm{v})$ formalin or $70 \%(\mathrm{v} / \mathrm{v})$ ethanol solution at $4{ }^{\circ} \mathrm{C}$ overnight. The cell residues were collected by centrifugation, washed three times in buffer and uniformly resuspended in the original volume of distilled water for coaggregation testing.

Preparation of S. sanguis cell walls. Cells of Ss 10557 were disrupted with the aid of glass beads $(0 \cdot 17-0 \cdot 18 \mathrm{~mm}$ diam.) in a Braun cell homogenizer (Model MSK, B. Braun Apparatebau, Melsungen, FRG). Cell walls were isolated by differential centrifugation at $13000 \mathrm{~g}$ for $60 \mathrm{~min}$ and then treated with trypsin as previously described (Bleiweis et al., 1964; Okahashi et al., 1983). A portion of the purified cell wall preparation was subjected to treatment with $5 \%(\mathrm{w} / \mathrm{v}) \mathrm{TCA}$ at $4{ }^{\circ} \mathrm{C}$ for $24 \mathrm{~h}$ (Okahashi et al., 1983). After extensive washings with distilled water, these native and extracted cell wall preparations were suspended in distilled water to give an $\mathrm{OD}_{550}$ of 0.75 .

Assay for coaggregation. The standard mixture consisted of $0.2 \mathrm{ml}$ each of the whole cell or cell wall suspensions of Av19246 and Ss10557 in a total volume of $0.6 \mathrm{ml} 40 \mathrm{~mm}$-Tris/HCl buffer, $\mathrm{pH} 7.5$. In some experiments, 4-80 mM-Tris/ $\mathrm{HCl}(\mathrm{pH} \mathrm{7-9)}$ and citrate phosphate buffers ( $\mathrm{pH} \mathrm{5-7)} \mathrm{were} \mathrm{used.} \mathrm{After} \mathrm{the} \mathrm{mixture} \mathrm{was} \mathrm{incubated}$ at $37^{\circ} \mathrm{C}$ for $5 \mathrm{~min}$, unless otherwise specified, cellular aggregation was examined macroscopically and scored as - (negative), \pm (questionable), $1+$ (weak) and $2+$ (marked). A control suspension containing either Av19246 cells or Ss 10557 cells (or cell walls) was always included.

Effects of various substances on coaggregation. Effects of the following substances on the bacterial coaggregation were examined : calcium chloride, magnesium chloride and potassium chloride at 0.1 to $10.0 \mathrm{mM} ; \mathrm{Na}_{2}$ EDTA and its metal-containing derivatives such as $\mathrm{Na}_{2} \mathrm{CaEDTA}, \mathrm{Na}_{2} \mathrm{MgEDTA}$ and $\mathrm{Na}_{2} \mathrm{MnEDTA}$ at $7.5 \mathrm{mM}$; glucose, galactose, fructose, rhamnose, mannose, lactose, fucose, melibiose, raffinose, sucrose, maltose, arabinose, xylose, sorbitol, xylitol, mannitol, inositol, glucosamine, galactosamine, mannosamine, $N$-acetyl-D-glucosamine, $N$ acetyl-D-galactosamine, $N$-acetyl-D-mannosamine (all reagent grade), and dextrans T10 and T250 (Pharmacia) at 3 to $600 \mathrm{mM}$. The serotype II-specific antigen of Ss 10557 was also used at final concentrations of from 0.01 to $0.5 \mathrm{mg} \mathrm{ml}^{-1}$. The antigen was extracted from the purified cell walls by cold $5 \%$ TCA treatment and purified by ion-exchange chromatography on a DEAE-Sephadex A-25 column followed by gel filtration through a Sephadex G-100 column (Koga et al., 1983). The polysaccharide antigen has been found to be composed of glucose, galactose, rhamnose and $N$-acetylgalactosamine at a molar ratio of $3: 6: 3: 2$, with a molecular weight of 4170 (calculated on the basis of the results obtained by chemical analyses).

Reversal of coaggregation was examined macroscopically after addition of carbohydrates to previously coaggregated bacteria.

Lectin-induced agglutination of $S$. sanguis whole cells and cell walls. Reaction mixtures contained $40 \mu \mathrm{g}$ dry wt of either cells or cell walls of $S$. sanguis and 20 or $200 \mu \mathrm{g}$ lectin in a total volume of $0.2 \mathrm{ml} 0.05 \mathrm{M}$-potassium phosphate buffer, $\mathrm{pH} 7 \cdot 0$. After incubation at $37^{\circ} \mathrm{C}$ for $2 \mathrm{~h}$, the mixtures were examined macroscopically for agglutination and scored as described above. Sources of the lectins used were as follows: Triticum vulgaris (wheat germ) agglutinin (WGA) and Ricinus communis (castor bean) agglutinin-120, (RCA-120, one of the ricins) from Vector Laboratories, Burlingame, Cal., USA; Glycine max (soybean) agglutinin (SBA) and Arachis hypogaea (peanut) agglutinin (PNA) from E.Y. Laboratories, San Mateo, Cal., USA; Phaseolus vulgaris agglutinin (phytohaemagglutinin, PHA) from Miles-Yeda, Kiryat Weizmann, Rehovot, Israel; and Canavalia ensifolmis (jack bean) agglutinin (ConA) from Sigma. 
Assay for the degradation of proteinaceous receptor on A. viscosus by cellular protease(s). A portion of Av19246 cell suspension in $40 \mathrm{~mm}$-Tris/ $\mathrm{HCl}$ buffer, $\mathrm{pH} 7.5$ was incubated at $37^{\circ} \mathrm{C}$ for $17 \mathrm{~h}$ in the absence or presence of $2 \mathrm{~mm}$ $\mathrm{Na}_{2}$ EDTA or $\mathrm{CaCl}_{2}, \mathrm{Na}_{2}$ EDTA being added to eradicate cell surface-bound $\mathrm{Ca}^{2+}$. Cells were removed by centrifugation, then supernatant was assayed for the amounts of proteinaceous cellular components released. Sedimented cells were tested for their ability to coaggregate with Ss 10557 as described above.

In order to test for the presence of proteolytic activity in Av19246, cells were incubated with $0.5 \%$ casein (Nakarai Chemicals, Kyoto, Japan) under the conditions described above. Unreacted casein was precipitated by the addition of $2.5 \%$ TCA and removed, together with cells, by centrifugation. The cell-free liquor obtained was assayed for the presence of digested casein measured as protein by the Lowry method with BSA as standard.

\section{RESULTS}

General nature of the coaggregation between the cells of $A$. viscosus and $S$. sanguis

Av19246 cells coaggregated markedly with Ss 10557 cells in $40 \mathrm{mM}$-Tris/HCl buffer. The optimal $\mathrm{pH}$ for the coaggregation was between 7.0 and 8.0 . The degree of coaggregation decreased with decreasing concentrations of the buffer. After standing at $37^{\circ} \mathrm{C}$ for more than $3 \mathrm{~h}$ in $40 \mathrm{~mm}$-buffer, $\mathrm{pH} 7 \cdot 5$, the aggregated masses dissociated gradually and almost completely disappeared after $6 \mathrm{~h}$ incubation. Even if $\mathrm{Ca}^{2+}$ was added at a concentration of $20 \mathrm{~mm}$ to the mixture containing the dissociated cells, coaggregation was not restored.

The cells of Av19246 and Ss 10557 did not form visible coaggregates in $4 \mathrm{~mm}$-Tris/ $\mathrm{HCl}$ buffer, $\mathrm{pH} 7 \cdot 5$. However, the presence of $\mathrm{Ca}^{2+}$ at $0.1 \mathrm{~mm}$ or higher or $\mathrm{Mg}^{2+}$ and $\mathrm{Mn}^{2+}$ at $0.5 \mathrm{mM}$ or higher in the buffer induced cellular coaggregation. The coaggregation was completely inhibited by the presence of $\mathrm{Na}_{2}$ EDTA, $\mathrm{Na}_{2} \mathrm{MgEDTA}$ or $\mathrm{Na}_{2} \mathrm{MnEDTA}$ at a concentration of $7.5 \mathrm{mM}$ in $40 \mathrm{~mm}$-buffer.

\section{Inhibitory effect of $\mathrm{Ca}^{2+}$ on the spontaneous dissociation of coaggregated cells}

Cells of Av19246 and Ss10557 were separately preincubated at $4{ }^{\circ} \mathrm{C}$ or $37^{\circ} \mathrm{C}$ for $17 \mathrm{~h}$ in $40 \mathrm{~mm}$-buffer, pH 7.5 and then coaggregation activity of these cells was tested. As shown in Table 1, cells of Ss 10557 incubated at $4{ }^{\circ} \mathrm{C}$ and $37^{\circ} \mathrm{C}$ retained the activity to react with untreated A. viscosus cells. Preincubation at $4^{\circ} \mathrm{C}$ also did not affect the coaggregating activity of Av19246 cells, but after incubation at $37^{\circ} \mathrm{C} \mathrm{A}$. viscosus cells lost the ability to coaggregate. However, the loss of activity was prevented by the presence of $1 \mathrm{mM}-\mathrm{Ca}^{2+}$ in the mixture during the preincubation.

No significant amount of solubilized protein was detected in the cell-free liquor of the preincubation mixture of Av19246 cells either in the absence or presence of $2 \mathrm{mM}-\mathrm{Na}_{2}$ EDTA or $\mathrm{Ca}^{2+}$ (Table 2). In addition, the cell-free liquor of the Av19246 digests showed no ability to inhibit the Av19246-Ss 10557 coaggregation reaction, and cell-free and/or cell-bound proteolytic activities were not detected with Av19246 cells under similar conditions (Table 2). These results

Table 1. Stabilization of the receptor on A. viscosus ATCC 19246 by the addition of $\mathrm{Ca}^{2+}$

Whole cells of both strains were separately incubated at $4{ }^{\circ} \mathrm{C}$ or $37^{\circ} \mathrm{C}$ for $17 \mathrm{~h}$ in $40 \mathrm{mM}-\mathrm{Tris} / \mathrm{HCl}$ buffer, $\mathrm{pH} 7.5$ in the absence or presence of $1 \mathrm{mM}-\mathrm{CaCl}_{2}$. They were then washed twice with buffer free from $\mathrm{CaCl}_{2}$. The reaction for coaggregation was performed in $40 \mathrm{mM}$-Tris/HCl buffer, $\mathrm{pH} 7 \cdot 5$. See text for classification of coaggregation.

\begin{tabular}{ccc}
\multicolumn{2}{c}{ Pretreatment $(17 \mathrm{~h})$} & \\
\cline { 1 - 2 } A. viscosus & S. sanguis & \\
$4{ }^{\circ} \mathrm{C}$ & $4^{\circ} \mathrm{C}$ & $2+$ \\
$37^{\circ} \mathrm{C}$ & $4^{\circ} \mathrm{C}$ & - \\
$4^{\circ} \mathrm{C}$ & $37^{\circ} \mathrm{C}$ & $2+$ \\
$37^{\circ} \mathrm{C}$ & $37^{\circ} \mathrm{C}$ & - \\
$37^{\circ} \mathrm{C}+\mathrm{CaCl}_{2}$ & $4^{\circ} \mathrm{C}$ & $2+$ \\
$37^{\circ} \mathrm{C}$ & $4^{\circ} \mathrm{C}+\mathrm{CaCl}_{2}$ & - \\
$37^{\circ} \mathrm{C}+\mathrm{CaCl}_{2}$ & $37^{\circ} \mathrm{C}$ & $2+$ \\
$37^{\circ} \mathrm{C}$ & $37^{\circ} \mathrm{C}+\mathrm{CaCl}_{2}$ & -
\end{tabular}


Table 2. Release of proteinaceous cellular substances from and proteolytic activity of $A$. viscosus ATCC 19246

The reaction was performed in $40 \mathrm{mM}-\mathrm{Tris} / \mathrm{HCl}$ buffer, $\mathrm{pH} 7 \cdot 5$, in the presence of $2 \mathrm{mM}-\mathrm{CaCl}_{2}$ or $\mathrm{Na}_{2}$ EDTA, with casein, when added, at a concentration of $5 \mathrm{mg} \mathrm{ml}^{-1}$.

$\begin{array}{lcc}\text { Proteinaceous substances } & \overbrace{2 \mathrm{mM}-\mathrm{CaCl}_{2}}^{\begin{array}{c}\text { Amount } \\ \text { or digested in the presence of: }\end{array}} \\ \text { Cellular proteins released } & 0.024 & 0.023 \\ \text { Casein digested } & 0.018 & 0.023\end{array}$

* Protein was estimated by the Lowry method with BSA as standard.

Table 3. Effects of various pretreatments of cells on the coaggregation between A. viscosus ATCC 19246 and S. sanguis ATCC 10557

The reaction was performed in $40 \mathrm{~mm}-\mathrm{Tris} / \mathrm{HCl}$ buffer, $\mathrm{pH} 7 \cdot 5$. See text for classification of coaggregation.

$$
\text { Organism }
$$

A. viscosus

ATCC 19246

sanguis

ATCC 10557
Pretreatment

None

Heat $\left(100^{\circ} \mathrm{C}, 1 \mathrm{~min}\right)$

Heat $\left(80^{\circ} \mathrm{C}, 5 \mathrm{~min}\right)$

Trypsin $\left(10 \mu \mathrm{g} \mathrm{ml}^{-1}\right)$

Formalin $(1 \%)$

Ethanol $(70 \%)$

None

Heat $\left(100^{\circ} \mathrm{C}, 1 \mathrm{~min}\right)$

Trypsin $\left(10 \mu \mathrm{g} \mathrm{ml}^{-1}\right)$
Coaggregation

$2+$

$-$

$-$

$-$

$1+$

$2+$

$2+$

$2+$

exclude the possibility that the presence of $\mathrm{Ca}^{2+}$ inhibits protease activity which might degrade or release a proteinaceous coaggregation receptor on Av19246 cells.

\section{Effects of various pretreatments of cells on the coaggregation}

The treatments of Av19246 cells with heat, trypsin and formalin abolished their ability to coaggregate with Ss 10557 cells (Table 3), indicating that a protein or glycoprotein on the cell surface of Av19246 may be involved in the coaggregation reaction. In contrast, the reactive site on the cell surface of Ss 10557 was resistant to the heat and trypsin treatments.

Inhibition of the coaggregation and dissociation of the coaggregates by sugars

Coaggregation was almost completely inhibited by the presence of $300 \mathrm{~mm}-\mathrm{N}$-acetylgalactosamine, $75 \mathrm{~mm}$-galactose, $18.8 \mathrm{~mm}$-lactose and $0.0112 \mathrm{~mm}$-carbohydrate antigen of Ss10557 (minimum concentrations; Table 4). Other carbohydrates tested were without effect even at a concentration of $600 \mathrm{mM}$. Addition of the D-galactosides at the concentrations indicated above, or higher, induced immediate dissociation of the previously aggregated cellular masses. Glucosamine and galactosamine also inhibited the coaggregation and caused dissociation of coaggregates.

\section{Reactivities of the $S$. sanguis whole cells and cell walls with various lectins and lectin-like} substances

The purified cell walls of Ss10557 showed Av19246-coaggregating activity similar to the whole streptococcal cells. However, the 5\% TCA-extracted cell wall residues lost the activity.

Cells and cell walls of Ss 10557 were tested for their ability to react with various lectins. It was found that of the lectins tested only RCA-120 produced agglutination of the cells and cell walls, but not of the extracted cell wall residue. The other lectins, PNA, PHA, SBA, WGA and ConA, did not react with Ss 10557 . 
Table 4. Effects of sugars and sugar derivatives on the coaggregation and disaggregation between A. viscosus ATCC 19246 and S. sanguis ATCC 10557

Negative results are recorded as - , and positive results as + . The minimal concentration that induced significant inhibition is given in parentheses.

$\quad$ Sugars and
sugar derivatives*
Distilled water
S. sanguis carbohydrate antigen $\dagger$
Glucose
Galactose
Lactose
Rhamnose
Fucose
Glucosamine
Galactosamine
Mannosamine
$N$-Acetylglucosamine
$N$-Acetylgalactosamine
$N$-Acetylmannosamine

$\begin{aligned} & \text { Coaggregation } \\ & \text { inhibition }\end{aligned}$
-
$+\left(375 \mu \mathrm{g} \mathrm{ml}^{-1}\right)$
-
$+(75 \mathrm{~mm})$
$+(18 \cdot 8 \mathrm{mM})$
-
-
$+(75 \mathrm{~mm})$
$+(75 \mathrm{~mm})$
-
-
$+(300 \mathrm{mM})$
-

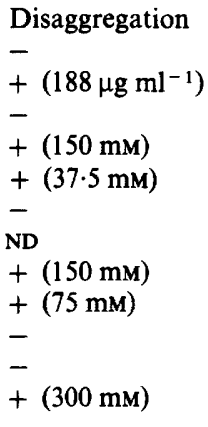

ND, Not determined.

* Other sugars and sugar derivatives listed in Methods were negative in both assays.

$\dagger$ Comprises glucose, galactose, rhamnose and $N$-acetylgalactosamine at a molar ratio of $3: 6: 3: 2$ (mol. wt 4170 - see Methods).

\section{DISCUSSION}

The results shown in Table 3 suggest that the coaggregation of Av19246 and Ss10557 involves the interaction of a proteinaceous substance on the cell surface of the actinomycete with a carbohydrate site on the streptococcus cell.

The essential role of $\mathrm{Ca}^{2+}$ in the lectin-carbohydrate cell-cell coaggregations between $A$. viscosus and $S$. sanguis has previously been reported (McIntire et al., 1978; Cisar et al., 1979). Our results show that the coaggregation between the Av19246 cells and Ss 10557 cells is also $\mathrm{Ca}^{2+}$-dependent. Complete inhibition of the coaggregation reaction by $\mathrm{Na}_{2} \mathrm{MgEDTA}$ seems to eliminate a possible $\mathrm{Mg}^{2+}$ dependency of the reaction. The coaggregates of Av19246 cells and Ss 10557 cells gradually dissociated and completely disaggregated after extended incubation at $37^{\circ} \mathrm{C}$. Addition of $\mathrm{Ca}^{2+}$ at $20 \mathrm{~mm}$ to the mixture did not restore coaggregation of the dissociated cells. This phenomenon is due to the spontaneous inactivation of a lectin-like binding site on the surface of Av19246 cells during the extended incubation at $37^{\circ} \mathrm{C}$ (Table 1). The presence of sufficient amounts $(1 \mathrm{mM})$ of $\mathrm{Ca}^{2+}$ repressed the denaturation of the reactive site, suggesting that the metal ion is sufficiently incorporated into, or in very close proximity to, the reactive site and thereby facilitates the preservation of structural integrity of the site. As shown in Table 2, neither activity of cell-free and cell-bound proteases nor the release of coaggregation-inhibitory proteinaceous substance(s) were detected with Av19246 cells during extended incubation at $37^{\circ} \mathrm{C}$. Thus, the detailed mechanism of the activity loss is obscure and remains to be elucidated.

The coaggregation between Av19246 and Ss10557, therefore, involves a $\mathrm{Ca}^{2+}$-dependent, lectin-carbohydrate cell-cell interaction which is lactose-reversible (Table 4). Mechanisms of coaggregation of this type have been studied with A. viscosus T14V (AvT14V) and S. sanguis 34 (Ss34). The properties of the protein counterpart on the cell surface of AvT14V have been elucidated biochemically, immunologically and morphologically (Cisar \& Vatter, 1979; Cisar et al., 1980; Revis et al., 1982) and a carbohydrate counterpart on Ss34 cell walls probably contains $\beta$-D-galactosides (McIntire et al., 1978; Cisar et al., 1979).

The native cell walls of Ss 10557 coaggregated with Av19246 cells, but the 5\% TCA-extracted cell wall residues did not. Moreover, the coaggregation was inhibited by the carbohydrate antigen extracted with 5\% TCA from the cell walls of Ss 10557 (Table 4). Experiments reported elsewhere (Koga et al., 1983) showed that the immunochemical reaction of the antigen extract with anti-serotype II antiserum is markedly inhibited by $\mathrm{N}$-acetylgalactosamine but little 
affected by galactose or lactose (Gal-( $1 \rightarrow 4)-\beta$-Glc). In contrast, lactose and galactose most effectively inhibited the coaggregation between Av19246 and Ss 10557 cells and disaggregated the preformed coaggregates (Table 4). $\mathrm{N}$-Acetylgalactosamine also exhibited an inhibitory activity but only at a higher concentration (16 times the concentration of lactose and 4 times that of galactose). These results indicate that the site of Ss 10557 cells reactive to Av19246 cells is part of the antigenic polysaccharide, but that the active region primarily involved in the coaggregation reaction is distinct from the immunodeterminant region.

McIntire et al. (1982) demonstrated that Gal-(1 $\rightarrow 3)-\beta-G a l N A c-\alpha-O-\mathrm{CH}_{2} \mathrm{C}_{6} \mathrm{H}_{5}$ and [Gal$(1 \rightarrow 3)-\beta$-GalNAc- $\alpha-O$-Thr-Ala-Ala $]_{4}$ exhibited remarkably high inhibitory activity (roughly $10-$ to 20-fold the activity of lactose) towards the coaggregation between AvT14V and Ss34, suggesting that the active portion of the coaggregation site on $S$. sanguis cells comprises a Gal$(1 \rightarrow 3)-\beta$-GalNAc- sequence. Only one of the lectins tested, RCA-120, which has a specific affinity for the $\beta$-D-galactose residue of the Gal-( $1 \rightarrow 4)-\beta$-GalNAc- sequence, agglutinated the Ss 10557 whole cells and cell walls (Table 4). Other lectins which recognize the terminal Dgalactose residue of the Gal-( $1 \rightarrow 3)-\beta$-GalNAc- sequence (PNA), or possess a specific affinity for $\beta$-GalNAc (SBA) and for GalNAc or Gal-( $1 \rightarrow 4)-\beta$-GlcNAc-( $1 \rightarrow 2)-\beta$-Man (PHA), did not react with cell surface component(s) of Ss10557. Therefore, based on these data, the active site on Ss 10557 cells for the coaggregation reaction appears to contain the sequence Gal-( $1 \rightarrow 4)-\beta$-Glc-.

In addition, D-fucose (6-deoxy-D-galactose) did not inhibit the coaggregation between Av19246 and Ss10557 (Table 3), in contrast to the findings that D-fucose and D-talose as well as D-galactose each inhibit equally the coaggregation of AvT14V and Ss34 (McIntire et al., 1982). Thus, detailed mechanisms of the cellular coaggregation must be different between these two pairs of $A$. viscosus and $S$. sanguis.

The inhibition of the coaggregation by glucosamine and galactosamine (Table 4) may be nonspecific, because these hexosamines were not detected in the carbohydrate antigen extract from Ss 10557 cell walls (Koga et al., 1983). However, there is sufficient similarity between GalNAc (one of the antigen components) and galactosamine for 'specific' inhibition to occur. Indeed, the inhibition by these hexosamines is more efficient than that by GalNAc (Table 4). It should be noted here that these hexosamines inhibit the reaction of the carbohydrate antigen with antiSs 10557 antiserum. Similar 'non-specific' inhibition by these hexosamines has been observed with the reactions of $S$. sanguis $b$ antigen and Lactobacillus plantarum cell wall teichoic acid with their homologous antisera (Knox \& Wicken, 1973; Appelbaum \& Rosan, 1978).

We are indebted to Drs Shigeyuki Hamada and Junn Mizuno for criticism and advice and also to Dr Floyd C. McIntire for reviewing the manuscript. Thanks are also due to Miss Eiko Ikehata for her expert typing of the manuscript.

\section{REFERENCES}

Appelbaum, B. \& Rosan, B. (1978). Antigens of Streptococcus sanguis: purification and characterization of the $b$ antigen. Infection and Immunity 21, 896-904.

Bleiweis, A. S., Karakawa, W. W. \& Krause, R.-M. (1964). Improved technique for the preparation of streptococcal cell walls. Journal of Bacteriology $\mathbf{8 8}$, $1198-1200$.

Cisar, J. O. \& VATTER, A. E. (1979). Surface fibrils (fimbriae) of Actinomyces viscosus T14V. Infection and Immunity 24, 523-531.

Cisar, J. O., Kolenbrander, P. E. \& McIntire, F. C. (1979). Specificity of coaggregation reactions between human oral streptococci and strains of Actinomyces viscosus or Actinomyces naeslundii. Infection and Immunity 24, 742-752.

Cisar, J. O., Barsumian, E. L., Curl, S. H., Vatter, A. E., Sanberg, A. L. \& Siraganian, R. P. (1980). The use of monoclonal antibodies in the study of lactose-sensitive adherence of Actinomyces viscosus T14V. Journal of the Reticuloendothelial Society 28, $73 \mathrm{~s}-79 \mathrm{~s}$

Ellen, R. P. \& BalCERzAK-RACZKowsKi, I. B. (1977). Interbacterial aggregation of Actinomyces naeslundii and dental plaque streptococci. Journal of Periodontal Research 12, 11-20.

GibBons, R. J. \& NyGAARD, M. (1970). Interbacterial aggregation of plaque bacteria. Archives of Oral Biology 15, 1397-1400.

Hamada, S., ToRi, M., Tsuchitani, Y. \& Kotani, S. (1980). Isolation and immunobiological classification of Streptococcus sanguis from human tooth surface. Infection and Immunity 12, 243-249.

JoRDAN, H. V. \& HAMmOND, B. F. (1972). Filamentous bacteria isolated from human root surface caries. Archives of Oral Biology 17, 1333-1342.

Jordan, H. V. \& KeYes, P. H. (1964). Aerobic, Grampositive filamentous bacteria as etiological agents of 
experimental periodontal disease in hamsters. Archives of Oral Biology 9, 401-411.

Knox, K. W. \& Wicken, A. J. (1973). Non-specific inhibition of the precipitin reaction between teichoic acids and antisera. Immunochemistry 10, 93-98.

Koga, T., OKahashi, N., Yamamoto, T., Mizuno, J., Inoue, M. \& Hamada, S. (1983). Purification and immunochemical characterization of Streptococcus sanguis ATCC 10557 serotype II carbohydrate antigen. Infection and Immunity 42, 696-701.

Kolenbrander, P. E. \& Williams, B. L. (1981). Lactose-reversible coaggregation between oral actinomycetes and Streptococcus sanguis. Infection and Immunity 33, 95-102.

McIntire, F. C., Vatter, A. E., Baros, J. \& Arnold, J. (1978). Mechanism of coaggregation between Actinomyces viscosus $\mathrm{T} 14 \mathrm{~V}$ and Streptococcus sanguis 34. Infection and Immunity 21, 978-988.

Mcintire, F. C., Crosby, L. K. \& Vatter, A. E.
(1982). Inhibitors of coaggregation between Actinomyces viscosus $\mathrm{T} 14 \mathrm{~V}$ and Streptococcus sanguis $34: \beta$ galactosides, related sugars, and anionic amphipathic compounds. Infection and Immunity 36, 371378.

Okahashi, N., Koga, T., Akada, H. \& Hamada, S. (1983). Purification and immunochemical characterizaton of Streptococcus sanguis serotype I carbohydrate antigen. Infection and Immunity 39, 552-558.

Revis, G. J., Vatter, A. E., Crowle, A. J. \& Cisar, J. O. (1982). Antibodies against the Ag2 fimbriae of Actinomyces viscosus $\mathrm{T} 14 \mathrm{~V}$ inhibit lactose-sensitive bacterial adherence. Infection and Immunity 36, 1217-1222.

Socransky, S. S., Manganiello, A. D., Propas, D., ORAM, V. \& VAN HouTe, J. (1977). Bacteriological studies of developing supragingival dental plaque. Journal of Periodontal Research 12, 90-106. 